\section{The Function of a Migration Corridor for a Passerine: A Case Study Based on Age and Gender of Blue-and-white Flycatcher (Cyanoptila cyanomelana)}

\author{
Bin Liu', ${ }^{1,2}$ Libo Wang ${ }^{2}$, Dandan Xue ${ }^{2}$, Peng Xü ${ }^{1}$, Yuting An ${ }^{2}$ and Changhu Lu ${ }^{1 *}$ \\ ${ }^{1}$ College of Biology and Environment, Nanjing Forestry University, Nanjing 210037, \\ China \\ ${ }^{2}$ Jiangsu Dafeng Milu National Nature Reserve, Yancheng 224136, China
}

\begin{abstract}
A B S T R A C T
Birds of different ages or sexes may select different migration strategies. We studied the spring and autumn migration as well as the body condition of different ages and sexes of the Blue-and-white Flycatcher Cyanoptila cyanomelana at a migration corridor in Yancheng, Jiangsu, China, in 2017. A total of 121 individuals were captured in mist nets, 62 in spring and 59 in autumn. We found that adult males were caught significantly earlier than females in both seasons (Mann-Whitney $U$ test, spring, $P=0.012$; autumn, $P=0.019$ ), but the migration timing of immature birds was much the same as adults of the same sex in both seasons (Mann-Whitney $U$ test, spring, $P=0.571$; autumn, $P=0.236$ ). Body size and sex were found to affect body mass significantly (ANCOVA, wing length $P=0.001$; sex $P=0.001$ ). No individuals were recaptured in both migration seasons, hence the Blue-and-white Flycatcher may adopt a strategy of one-day stopovers. The Yancheng seawall forest may represent a low-quality habitat for this species, and birds pass this location quickly in search of other suitable habitats.
\end{abstract}

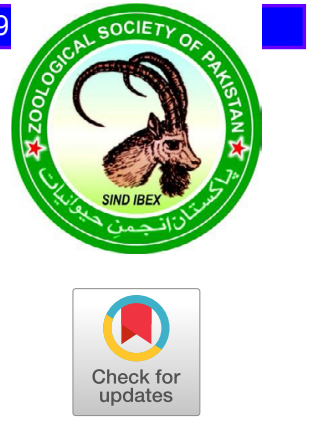

Article Information

Received 20 June 2019

Revised 30 July 2019

Accepted 17 September 2019

Available online 28 June 2021

Authors' Contribution

CL and BL designed the study and wrote this article. $L W, D X$ and YA helped in field survey and collected the data. PX helped in editing the manuscript.

\section{Key words}

Blue-and-white flycatcher, Protandry,

Body condition, Timing of migration,

Age and sex

\section{INTRODUCTION}

$\mathrm{B}$ irds regularly migrate between their breeding and wintering grounds allowing them to adapt to the changing environment while adjusting their migratory behavior and migration time in a way that maximizes their reproductive success and/or survival (Gienapp et al., 2014). However, birds need to consume large amounts of energy during migration; therefore, most long-distance migratory birds must stopover at feeding grounds to replenish their energy before completing migration. Therefore, establishing patterns of migratory connectivity at the population level is important; this involves linking breeding and wintering grounds as well as migratory stopover sites (González-Prieto et al., 2011; Hobson et al., 2014).

Migratory birds usually have differential migration strategies based on gender and age. Protandry occurs when males precede females when arriving at breeding grounds, stopover sites, or wintering places (Rubolini et al., 2004; Markovets et al., 2008; Tøttrup and Thorup, 2008; Mckinnon et al., 2016). Protogyny occurs when females precede males during spring or fall migration

\footnotetext{
Corresponding author: luchanghu@njfu.edu.cn 0030-9923/2021/0005-1695 \$ 9.00/0

Copyright 2021 Zoological Society of Pakistan
}

(Oring and Lank, 1982; Reynolds et al., 1986). Most scholars generally believe that adults arrive at breeding grounds, stopovers, or wintering places earlier than immatures (Dariusz and Wojczulanis-Jakubas, 2010; Mckinnon et al., 2016). Several possible factors have been suggested to explain these patterns, such as the differences in body size and physiology between the sexes (Møller, 2004; Saino et al., 2010), the pressure of sexual selection on the breeding ground, and even the differential investment in breeding (Meissner and Kamont, 2005; Studds and Marra, 2011; Maggini and Bairlein, 2012). For subadults, the lack of migration experience, low foraging efficiency, and poor ability to resist predatory risk often result in a lower migration speed; thus, subadults arrive at their destination later than adults (Moore and Yong, 1991; Aborn, 1994).

The blue-and-white flycatcher is a small bird that belongs to the family of old world flycatchers (Muscicapidae, Passeriformes). During spring, this species migrates to Changbai Mountain and the small Xing'an Ridge in northeast China or North Korea, Japan, for breeding, crossing the east coast of Jiangsu Province, China during migration. In autumn, the birds return from the breeding grounds to their wintering places, such as Guangdong and Hainan province of China and Malaysia and the Philippines (Qian et al., 1982). The prefecture- 
level city of Yancheng in northeast Jiangsu is almost in the middle of the migration route and serves as a very important stopover for many species. Nevertheless, little is known about the migration phenology of the blue-andwhite flycatcher in the Yancheng stopover.

We studied the spring and autumn migration phenology of the male and female blue-and-white flycatcher Cyanoptila cyanomelana in the Yancheng coastal region, with regard to their age and body condition. We hypothesized that the blue-and-white flycatcher would show different migration patterns between sexes, with protandry in spring and autumn. We hypothesized that the body mass of males would be higher than females, because the males appeared to be larger. We also hypothesized that the habitat of the Yancheng seawall forest maybe a very important corridor to the migratory passerines.

\section{Study sites}

This study was carried out at Dafeng Milu National Nature Reserve, Yancheng City, Jiangsu Province, China $\left(32^{\circ} 59^{\prime} \mathrm{N}-33^{\circ} 03^{\prime} \mathrm{N}, 120^{\circ} 47-120^{\circ} 53^{\prime} \mathrm{E}\right)$, one of the most important stopover sites for migratory birds. The reserve, located on the eastern coast of Jiangsu Province, was established to protect a typical coastal beach wetland. The average elevation is $2-4 \mathrm{~m}$. The climate falls between the subtropical and warm temperate zones with an annual average temperature of $14.1^{\circ} \mathrm{C}$ and an annual average precipitation of $1068 \mathrm{~mm}$ of which about $63 \%$ falls from June to September. Fieldwork was performed from $7^{\text {th }}$ April to $31^{\text {st }}$ May, and from $3^{\text {rd }}$ September to $31^{\text {st }}$ October, 2017, covering almost the entire passerine migration time in spring and fall.

Our study sites were in the seawall forest. The seawall forest, as defined here, grows behind the seawall parallel to and between the sea and road, and is about 20 meters wide. That is, open wetland habitat lies one side of the road while farmland stands on the other (Fig. 1). Between the seawall forest and the wetland/farmland the main plants are Imperata cylindrica and reed Phragmites communis. No other typical forest habitat exists within 10 $\mathrm{km}$. The dominant trees in the seawall forest are Robinia pseudoacacia with a height of 8-10 m, including a small number of other trees such as Ligustrum lucidum. The shrub layer vegetation mainly includes Rosa multiflora, Lycium barbarum, Morus alba, and herbs and vines such as Phytolacca americana, Paederia scandens, and Cayratia japonica.

Many bird species use the seawall forest during migration, especially small songbirds such as Arctic Warbler Phylloscopus borealis, yellow-browed warbler Phylloscopus inornatus, eastern crowned warbler Phylloscopus coronatus, and Asian brown flycatcher
Muscicapa latirostris, grey-streaked flycatcher Muscicapa griseisticta, and Mugimaki flycatcher Ficedula mugimaki.

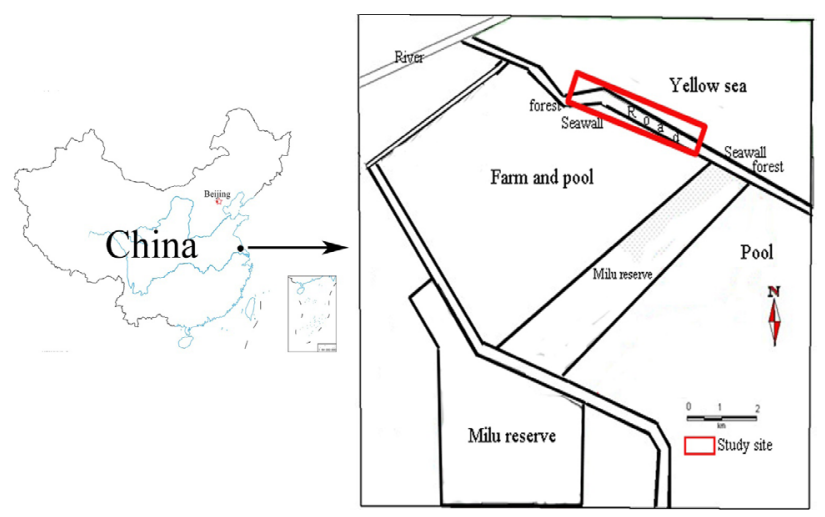

Fig. 1. Location of the study site in Yancheng seawall forest, China.

\section{MATERIALS AND METHODS}

Captured the birds in eight mist nets (each $12 \mathrm{~m}$ long, $3 \mathrm{~m}$ high, with a $36 \mathrm{~mm}$ mesh) placed in the seawall forest along the sea embankment road; the distance between each net was about $300 \mathrm{~m}$. Mist nets were placed perpendicular to the road; the number of nets and their locations were similar among days and seasons. Nets were opened daily from 0600 to 1700 (net opened $11 \mathrm{~h}$ each day) except for days with rain and wind (spring, 5 days; autumn, 5 days); nets checked every hour. The captured period of blue-and-white flycatcher was carried out from $18^{\text {th }}$ April to $16^{\text {th }}$ May in spring, and from $7^{\text {th }}$ September and $6^{\text {th }}$ October in autumn, 2017.

Birds were banded with uniquely numbered metal bands from National Bird Banding Center, China. For all the blue-and-white flycatchers, we recorded date and time of capture, age, and sex (Brazil, 2009). We also measured the right wing with a ruler $( \pm 0.1 \mathrm{~cm})$ to provide a surrogate measure of body size. Body mass was measured using an electronic scale $( \pm 0.1 \mathrm{~g})$ (Manufacturer: Airui Trading Co., Ltd., Yongkang, Zhejiang, China; Maximum range: $200 \mathrm{~g}$ ). The bird was released as soon as possible.

In spring, the first date for capture of this species was $18^{\text {th }}$ April (April 18= Day 1 of spring banding); the last capture date was $16^{\text {th }}$ May (May 16= Day 29 of spring banding). In autumn, the first date for capture of the bird was $7^{\text {th }}$ September (September 7= Day 1 of autumn banding), the last captured date was $6^{\text {th }}$ October (October $6=$ Day 29 of autumn banding). Days with no birds captured were recorded as 0 . 


\section{Data analysis}

We compared the median migration dates of each sex using different age classes both in spring and autumn to get an overview of the migration pattern of this species using a Mann-Whitney $U$ test.

We found that the individuals coming to our study site were almost fat-free, with the fat score classified from 0 (almost no fat) to 1 (a little fat), according to Kaiser (1993). Therefore, we used the measured body mass as the lean body mass. Analysis of covariance was used to analysis the relationship between the body mass and the body size, age, sex, and season. Taking body mass as the dependent variable and body size (wing length) as the covariate, we then used age, sex, and season as fixed factors.

We compared the difference in body mass between ages and sexes by $t$-test. The significance level was 0.05 . All analyses were carried out in SPSS 21.0 and Origin 7.5.

\section{RESULTS}

\section{Bird captured number}

A total of 121 individuals of blue-and-white flycatcher were captured in 2017. Sixty-two were captured in spring and 59 in autumn, the sex ratios were 1:0.7 in spring and $1: 0.8$ in autumn, and the ratios of adults to immatures were 1:0.2 and 1:0.5, respectively.

Most birds were captured in May in spring and September in autumn with 44 and 55 birds captured in those months, respectively (Fig. 2).

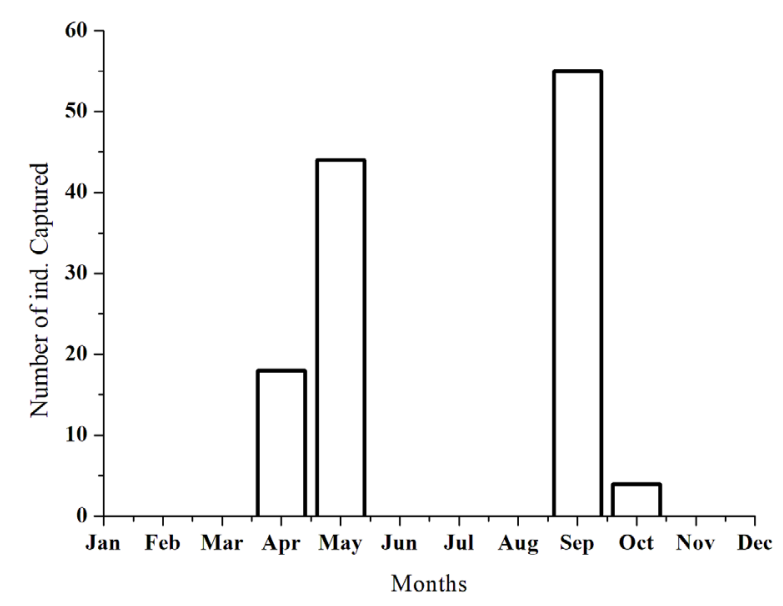

Fig. 2. The number of blue-and-white flycatchers captured in different months.

\section{Timing of migration phenology}

In spring, blue-and-white flycatchers were captured on $18^{\text {th }}$ April and $16^{\text {th }}$ May, which means that the species visited the Yancheng stopover site during a period of at least 29 days in spring. The number of birds captured per day increased gradually from the date of the initial capture, peaking on $12^{\text {th }}$ May and then declining rapidly; No individual of this species was captured after $16^{\text {th }}$ May (Fig. $3 a)$. In autumn, the trend of the number of captured birds per day varied little with two peaks, one on $8^{\text {th }}$ September and another around $22 / 23^{\text {rd }}$ September. The initial capture occurred on $7^{\text {th }}$ September in autumn and ended after 6 th October (Fig. 3b). The birds stayed at this stopover location for at least 29 days.
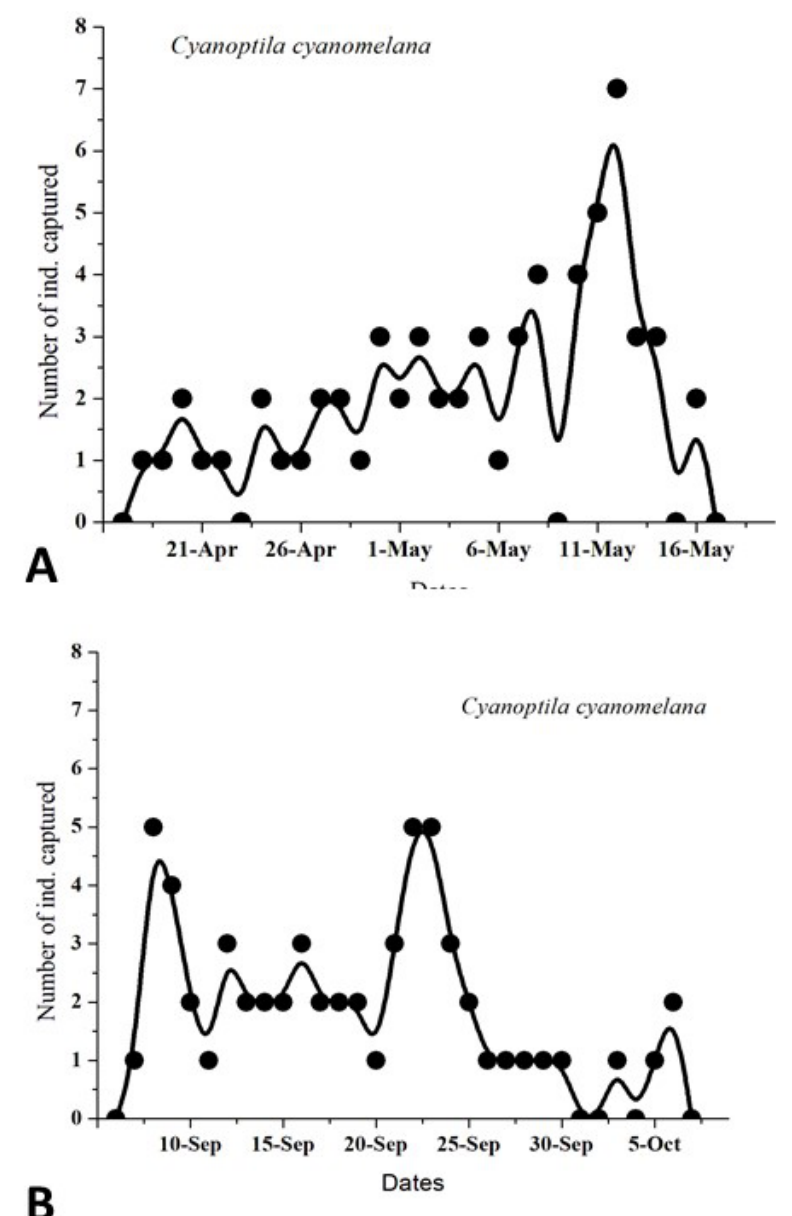

Fig. 3. The number of blue-and-white flycatchers captured per day in different seasons: (A) spring, (B) autumn.

In spring, the median capture dates for different sex and age groups ranged from $29^{\text {th }}$ April to $7^{\text {th }}$ May. For adults, the timing of migration differed significantly between sexes (Mann-Whitney $U$ test, $Z=-2.492, P=$ 0.012 ), with the median date for males being 8 days earlier than for females. Immature males and females migrated at a similar time as adults of the same sex (Mann-Whitney $U$ test, $Z=-0.745, P=0.571$ ), with only a 2-day difference 
between median dates for both sexes. No significant difference of median capture date was observed between adult and immature males (Mann-Whitney $U$ test, $Z=$ $-0.705, P=0.481$ ), while the timing of migration was similar for adult and immature females (Mann-Whitney $U$ test, $Z=-1.828, P=0.068$, Fig. $4 \mathrm{a})$.
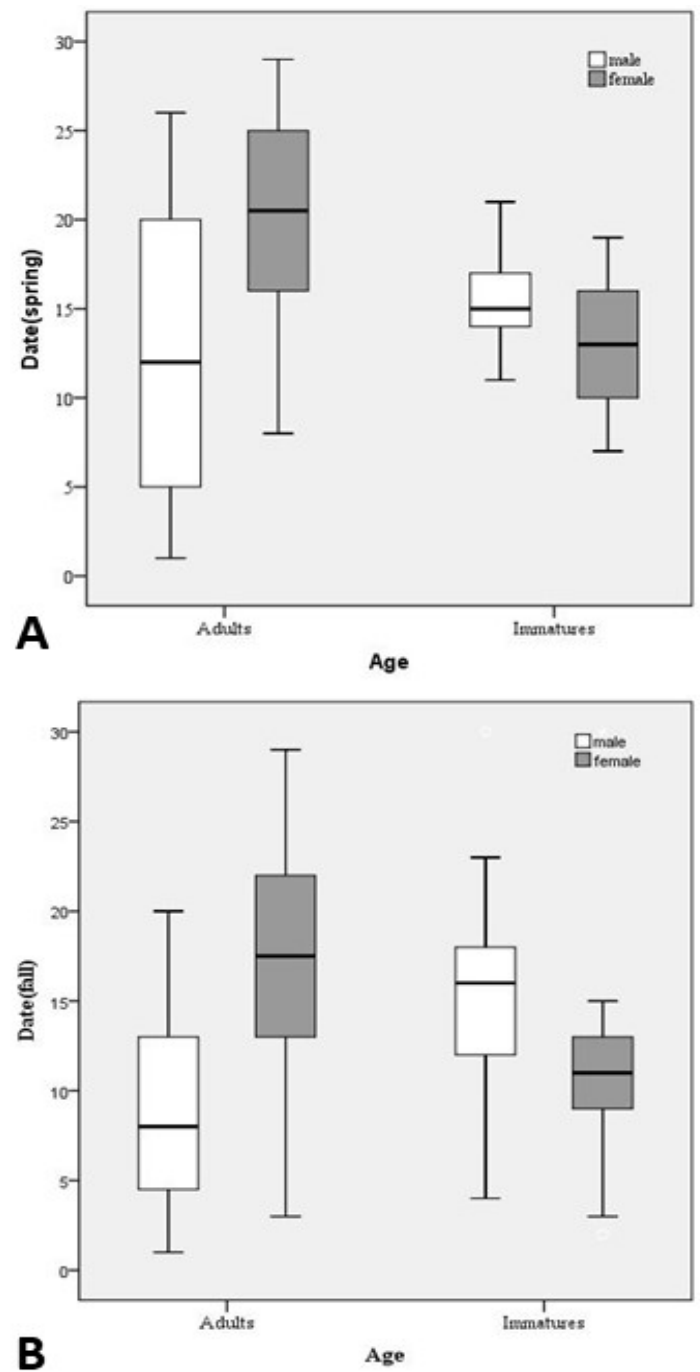

Fig. 4. Timing of migration of blue-and-white flycatchers for both ages and sexes in (A) spring and (B) autumn.

In autumn, the median capture dates for different sex and age groups ranged from $14^{\text {th }}$ September to $23^{\text {rd }}$ September. In adults, the median date for males was 11 days earlier than for females (Mann-Whitney $U$ test, $Z=$ $-2.313, P=0.019)$. Immature males and females migrated at an almost similar time as adults of the same sex (MannWhitney $U$ test, $Z=-1.204, P=0.236)$. Adults and immature birds of both males (Mann-Whitney $U$ test, $Z=$
-1.884, $P=0.06$ ) and females (Mann-Whitney $U$ test, $Z=$ $-1.432, P=0.152)$ birds migrated at the same time for the respective sexes (Fig. 4b)

\section{Body condition}

Body mass was not affected by age (ANCOVA, $F_{1,116}=$ $3.869, P=0.052$ ) or by season (ANCOVA, $F_{1,116}=0.948$, $P=0.332)$. However, body size and sex were found to affect body mass (ANCOVA, wing length $F_{1,116}=12.854$, $P=0.001$; ANCOVA, sex $F_{1,116}=11.894, P=0.001$ ).

In adults, body mass was significantly higher in males than females ( $t$ test, $t=3.640, d f=88, P=0.001, n=90$ ). In immatures, body mass was also higher in males than females ( $t$ test, $t=3.980, d f=29, P=0.001, n=31$; Fig. 5).

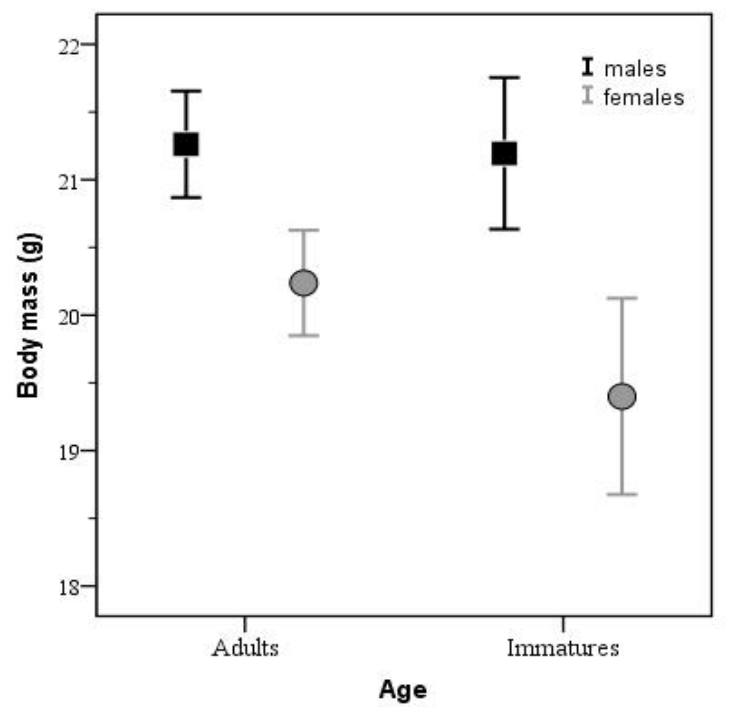

Fig. 5. Body mass in blue-and-white flycatcher of both sex and age categories during spring and autumn.

\section{DISCUSSION}

In our study, differences were observed based on sex in the spring and autumn migration patterns in blueand-white flycatcher, with males migrating significantly earlier than females. This migration pattern accords with a protandry strategy, which is the same as the findings of many former research studies on other species (CárdenasOrtiz et al., 2017; Barton and Sandercock, 2018). In spring, adult males of many species normally travel earlier from wintering sites to breeding sites than females to occupy high-quality breeding territory and to maximize their reproductive success through mate selection (Coppack et al., 2006; Canal et al., 2012). This supports the timeminimization strategy, which assumes that birds migrate as rapidly as possible given constraints on traveling speed 
and fuel deposition rate (Hedenström and Alerstam, 1997; Kokko, 1999). In our study, the adult male blue-and-white flycatcher arrived at breeding sites earlier than females in spring to gain an advantageous position in the fierce reproductive competition, and they also appeared earlier than the females at the Yancheng stopover.

The breeding system and migratory behavior will affect the timing of migration based on the breeding investment hypothesis (Doligez et al., 2004; Mills, 2005; Eichhorn et al., 2017). An investment in breeding may have carry over influence and effects when either sex is able to start migration. In some species, females depart in autumn soon after the chicks hatch, leaving the males to take care of the young; then, the males must depart after the chicks have fledged and become independent (Meissner and Kamont, 2005; Meissner and Krupa, 2009). Nevertheless, in passerines, females usually invest more in breeding than males, which may delay their time of departure in autumn (Jenni and Winkler, 1994; Newton, 2011). A study of breeding behavior of blue-andwhite flycatcher in Heilongjiang Province showed that female blue-and-white flycatcher invested more time in incubating eggs, feeding the offspring, warming the nest, and clearing feces than males. This shows that females of this species invest more energy in breeding than males (Li et al., 2017). Therefore, investing more than males in breeding delayed the departure time of females, so that they arrived at the stopover site later. However, we found immature birds of both sexes migrating at a similar time. This result is similar to findings for another species of Aquatic Warbler Acrocephalus paludicola as well as with duck and shorebird species (Newton, 2011).

We found that the body mass of males in both ages was higher than that of females, as has been reported in other studies of other species (Yosef and Chernetsov, 2004; Zakala et al., 2004; Zhao et al., 2017). The male blue-and-white flycatcher has a larger body size than females and they have efficient foraging strategies based on experiences or by having higher social status than immatures or females at stopover sites. At the study site, no individuals were recaptured in both migration seasons; we suspect that blue-and-white flycatcher may adopt a strategy of one-day stopovers. The Yancheng seawall forest maybe a migration corridor or a low-quality stopover for this species according to the strategy of oneday stopover adopted by it (Cárdenas-Ortiz et al., 2017), and birds pass through this place quickly in search of more suitable habitats. As a result, further study is needed to consider the possible importance of other stopover sites for this species of bird.

\section{CONCLUSION}

Blue-and-white flycatcher exhibited sex-based differences in the migration pattern, with males migrating significantly earlier than females for both adults and immature birds. In addition, we found that the body masses of both adults and immature males were higher than that of females. The Yancheng site was an important migratory corridor for blue-and-white flycatcher in both spring and autumn.

\section{Statement of conflict of interest}

The authors declare there is no conflict of interest.

\section{REFERENCES}

Aborn, D., 1994. Correlation between raptor and songbird numbers at a migratory stopover site. Wilson Bull., 106: 150-154.

Barton, G.G. and Sandercock, B.K., 2018. Long-term changes in the seasonal timing of landbird migration on the Pacific Flyway. Condor, 120: 30-46. https:// doi.org/10.1650/CONDOR-17-88.1

Brazil, M., 2009. Field guide to the birds of East Asia. Christoppher Helm Press, London, U.K.

Canal, D., Jovani, R. and Potti, J., 2012. Multiple mating opportunities boost protandry in a pied flycatcher population. Behav. Ecol. Sociobiol., 66: 67-76. https://doi.org/10.1007/s00265-011-1253-8

Coppack, T., TØttrup, A.P. and Spottiswoode, C., 2006. Degree of protandry reflects level of extrapair paternity in migration songbirds. J. Ornithol., 147: 260-265. https://doi.org/10.1007/s10336-0060067-3

Cárdenas-Ortiz, L., Bayly, N.J., Colorado, Z.G.J. and Hobson, K.A., 2017. Fall migration and breeding origins of Canada Warblers moving through northern Colombia. J. Field Ornithol., 88: 1-12.

Dariusz, J. and Katarzyna, W.J., 2010. Sex and agerelated differences in the timing and body condition of migrating Reed Warblers Acrocephalus scirpaceus and Sedge Warblers Acrocephalus schoenobaenus. Naturwissenschaften, 97: 505511. https://doi.org/10.1007/s00114-010-0666-y

Doligez, B., Pärt, T. and Danchin, E., 2004. Prospecting in the collared flycatcher: gathering public information for future breeding habitat selection? Anim. Behav., 67: 457-466. https://doi. org/10.1016/j.anbehav.2003.03.010

Eichhorn, G., Bil, W. and Fox, J.W., 2017. Individuality in northern lapwing migration and its link to timing of breeding. J. Avian Biol., 48: 01-07. https://doi. 
org/10.1111/jav.01374

Gienapp, P., Reed, T.E. and Visser, M.E., 2014. Why climate change will invariably alter selection pressures on phenology? Proc. biol. Sci., 281: 1-8. https://doi.org/10.1098/rspb.2014.1611

Gonzalez-Prieto, A.M., Hobson, K.A. and Bayly, N.J., 2011. Geographic origins and timing of fall migration of the Veery in northern Colombia. Condor, 113: 860-868.

Hedenström, A., and Alerstam, T., 1997. Optimum fuel loads in migratory birds: distinguishing between time and energy minimization. J. Theoret. Biol., 189: 227-234. https://doi.org/10.1006/jtbi.1997.0505

Hobson, K.A., Van Wilgenburg, S.L., Faaborg, J., Toms, J.D., Rengifo, C., Sosa, A.L., Aubry, Y., and Aguilar, R.B., 2014. Connecting breeding and wintering grounds of Neotropical migrant songbirds using stable hydrogen isotopes: a call for an isotopic atlas of migratory connectivity. J. Field Ornithol., 85: 237-257. https://doi.org/10.1111/jofo. 12065

Jenni, L., and Winkler, R., 1994. Moult and ageing of European passerines. Academic Press, London, U.K.

Kaiser, A., 1993. A new multi-category classification of subcutaneous fat deposits of songbirds. J. Field Ornithol., 64: 246-255.

Kokko, H., 1999. Competition for early arrival in migratory birds. J. Anim. Ecol., 68: 940-950. https://doi.org/10.1046/j.1365-2656.1999.00343.x

Li, D.W., Zhao, W.G., Liu, P., Yu, D. and Chen, H., 2017. A study on the reproductive behavior of the Blue-and-white flycatcher in eastern Heilongjiang Province. Heilongjiang Anim. Sci. Vet. Med., 529: 229-233.

Maggini, I., and Bairlein, F., 2012. Innate sex differences in the timing of spring migration in a songbird. PLoS One, 7: e31271. https://doi.org/10.1371/ journal.pone.0031271

Markovets, M.L., Zduniak, P., and Yosef, R., 2008. Differential sex- and age-related migration of Bluethroats Luscinia svecica at Eilat, Israel. Naturwissenschaften, 95: 655-661. https://doi. org/10.1007/s00114-008-0371-2

Mckinnon, E.A., Macdonald, C.M., Gilchrist, H.G. and Love, O.P., 2016. Spring and fall migration phenology of an Arctic-breeding passerine. $J$. Ornithol., 157: 681-693. https://doi.org/10.1007/ s10336-016-1333-7

Meissner, W., and Kamont, P., 2005. Seasonal changes in body size and mass of red knots Calidris canutus during autumn migration through southern Baltic. Ornis Svecica, 15: 97-104.
Meissner, W., and Krupa R., 2009. Biometrics of the Dunlin (Calidris alpina) migrating in autumn along the Polish Baltic coast. Ring, 31: 3-13. https://doi. org/10.2478/v10050-008-0044-8

Mills, A.M., 2005. Protogyny in autumn migration: Do male birds "play chicken"? Auk, 122: 71-81. https://doi.org/10.1093/auk/122.1.71

Moore, F.R., and Yong, W., 1991. Evidence of foodbased competition during migratory stopover. Behav. Ecol. Sociobiol., 28: 85-90. https://doi. org/10.1007/BF00180984

Newton, 1., 2011. Migration within the annual cycle: species, sex ang age differences. J. Ornithol., 152: 169-185. https://doi.org/10.1007/s10336-0110689-y

Møller, A.P., 2004. Protandry, sexual selection and climate change. Global Change Biol., 10: 2028-2035. https://doi.org/10.1111/j.13652486.2004.00874.x

Oring, L.W., and Lank, D.B., 1982. Sexual selection, arrival times, philopatry and site fidelity in polyandrous spotted sandpiper. Behav. Ecol. Sociobiol., 10: 185-191. https://doi.org/10.1007/ BF00299684

Qian, G.Z., Zhu, L.B., and Cui, Z.X., 1982. An observation on energetic metabolism of the migratory insectivorous birds Ficedula cyanomelana cumatilis. Acta Ecol. Sin., 2: 279284.

Reynolds, J.D., Colwell, M.A. and Cooke, F., 1986. Sexual selection and spring arrival times of rednecked and Wilson's phalaropes. Behav. Ecol. Sociobiol., 18: 303-310. https://doi.org/10.1007/ BF00300008

Rubolini, D., Spina, F. and Saino, N., 2004. Protandry and sexual dimorphism in trans-Saharan migratory birds. Behav. Ecol., 15: 592-601. https://doi. org/10.1093/beheco/arh048

Saino, N., Rubolini, D., Serra, L., Caprioli, M., Morganti, M., Ambrosini, R. and Spina, F., 2010. Sex-related variation in migration phenology in relation to sexual dimorphism: a test of competing hypotheses for the evolution of protandry. J. Evolut. Biol., 23: 2054-2065. https://doi.org/10.1111/j.14209101.2010.02068.x

Studds, C.E., and Marra, P.P., 2011. Rainfall-induced changes in food availability modify the spring departure programme of a migratory bird. Biol. Sci., 278: 3437-3443. https://doi.org/10.1098/ rspb.2011.0332

Tøttrup, A.P., Thorup, K., 2008. Sex-differentiated migration patterns, protandry and phenology in 
North European songbird populations. J. Ornithol., 149: 161-167. https://doi.org/10.1007/s10336007-0254-X

Wojczulanis-Jakubas, K., Jakubas, D., Foucher, J., Dziarska-Palac, J. and Dugué, H., 2013. Differential autumn migration of the aquatic warbler Acrocephalus paludicola. Naturwissenschaften, 100: 1095-1098. https://doi.org/10.1007/s00114013-1108-4

Yosef, R. and Chernetsov, N., 2004. Stopover ecology of migratory Sedge Warblers (Acrocephalus schoenobaenus) at Eilat, Israel. Ostrich, 75: 52-56. https://doi.org/10.2989/00306520409485412
Zakala, O., Shydlovskyy, I. and Busse, P., 2004. Variation in body mass and fat reserves of Sedge Warbler Acrocephalus schoenobaenus on autumn migration in the L'viv Province (W Ukraine). Ring, 26: 55-69. https://doi.org/10.2478/v10050-0080069-z

Zhao, M.J., Christie, M., Coleman, J., Hassell, C., Gosbell, K., Lisovski, S., Minton, C. and Klaassen, M., 2017. Time versus energy minimization migration strategy varies with body sizeand season in long-distance migratory shorebirds. Movement Ecol., 5: 23. https://doi.org/10.1186/s40462-0170114-0 